\title{
Intangible Assets, Competitive Strategy And Financial Performance: Study On Rattan SMEs In Palu City Of Central Sulawesi (Indonesia)
}

\author{
Husnah $^{1}$, Bambang Subroto ${ }^{2}$, Siti Aisjah ${ }^{3}$ and Djumahir ${ }^{4}$ \\ ${ }^{1,2,3,4}$ Faculty of Economic and Business, Brawijaya University Malang, East Java, Indonesia
}

\begin{abstract}
The purpose of this study is to test and analyzing the direct influence of intangible assets (human, organizational and relational capital) on competitive strategy and financial performance. The research approach used is positivist paradigm, based on quantitative research. The method used is explanatory survey method. The unit of analysis is the Rattan SMEs in Palu. Respondents were 38 owners or managers of Rattan SMEs. Primary data is collected through questionnaires and interviews. Data analysis method used was Partial Least Square (PLS). Results of this study indicate that human capital and relational capital does not directly affect financial performance, only indirectly affect organizational capital to improve financial performance. Intangible assets (human capital, organizational capital and relational capital) can directly increase the accuracy of competitive strategy selection and competitive strategy directly affect financial performance. It can be proved that integration model intangible assets increase financial performance maximally when mediated by a competitive strategy selection. Practical Implications of the study is to provide information to managers or owners of SMEs, namely government and policy makers, about the importance of intangible assets investment which are basis for determining competitive strategy to achieve more optimal rattan SMEs financial performance, controlling for external factors in future in order internal factors to be prepared for Rattan SMEs development.
\end{abstract}

Keywords - financial performance, intangible asset, strategy

\section{INTRODUCTION}

Financial performance assessment in Small and Medium Enterprises (SMEs) is essential to maintain the business viability. Companies with small and medium scale describe their business development in modest financial performance. For example, achieving sales targets, return on capital, profit and growth performance. Generally, few studies measure SMEs financial performance to assess the sales level, probfitability, sales growth and profit growth $[1,2,3,4,5,6,7,8,9,10,11]$.

One solution to overcome the problems affecting SMEs financial performance is through business management of Resource-Based. With these arrangements, company able to create a special competence [12.13]. Resources Based Value (RBV) theory suggests that resources and capabilities are basis to create a strategy. Strategy chosen should allow company to use its core competencies for opportunities in external environment. The problem is, not all companies have potential resources and capabilities as a basis for competitive advantage. Intangible resources are better to produce competitive advantage consistently [14]. Therefore, in value creation, the focus shifted from the use of individual assets into a group of assets, primarily intangible assets. Thus, intangible resources are a strategic asset that can create SCA (Sustainable Competitive Advantage), because it meets the criteria of Valuable, Rare, Perfectly imitable, non-substitutable (VRIN) [12].

Intangible assets [15] is the source material (it is not financial assets / financial capital or physical resources such as fixed assets). As a factor of production, Intangible assets play an important role in company's value creation process in order to compete successfully. It consists of human capital, relationship capital and structural capital. Intangible assets using RBV theory. The assumption is that every company have collection of unique resources and capabilities are basis for determining strategy and is main source of company return [16], reflected in company financial performance.

Companies achieve competitive advantage by leveraging the unique resources and strategies [12.17]. Resources and strategies is a key element for management decisions to determine the long-term company performance [17]. In this context, RBV predicts that firms with many intangible resources will have greater SCA [19]. SCA can not be achieved apart from RBV that directing corporate management to identify, retain and develop strategic resources in order to produce optimal performance [20]. Optimal performance can be achieved if company has a set of homogeneous resources, or factors of production to produce different financial performance [21].

Financial performance that can be achieved from competitive advantage of a nation will correlates directly with the nation's collective capability to produce, distribute, and apply knowledge in economy. 
Investment knowledge in developing countries is relatively small and does not have significant leverage on economic growth [22]. The most significant weakness of developing countries is they difficult to achieve progress in human capital, structural capital/organizational capital and customer capital / relational capital. Education and training system is not optimal in generating human capital. They incapable to innovate in face problems and rapidly change environment. This condition is exacerbated by poor organizational capital, particularly social, cultural, educational, legal, political and economic development. In addition, relational capital is not built from the beginning and there is a lack of information networks about local and global markets. Third problems source of developing countries are part of Intangible/Knowledge/Intellectual Capital [22].

RBV, by looking the relationship of "business-strategy-performance", is refer to Porter's generic strategies [23]. The substance of his thinking is a competitive advantage can be obtained only if company has right competitive strategy. According to Porter [24], there are three types of competitive strategy: cost leadership, differentiation and focus. Typology of competitive strategy is consistent with resource-based perspective, where the VRIN criteria is a very fundamental aspect of competitive strategy to achieve success, especially to create value [23]. Company's strategy is an important part of company's organizational system, which will play an important role in improving business performance [25,26,27]. Much research supports the direct influence of the porter's competitive strategy on financial performance [28,29].

Strategic resource that owned and controlled by corporation is used as a base formulation and implementation of strategies to achieve optimal business performance [13, 17]. Furthermore, sustainability or corporate excellence depends on resources, and strategy chosen to empower those resources to respond the opportunities and challenges of external environment [12]. Selection strategy [30] is a decision to choose the best strategy to meet corporate objectives. Decisions taken involving decisions on alternatives, consideration of selection factors, assessment of various alternatives and true selection criteria. This means, selection strategy based on selective resource to achieve company's goal. Think about integration or compatibility strategy described as "model fit" to be implemented properly by company [27]. This means essential strategies integration to provide compatibility between strategy with several contingency variables. It can help define strategies to achieve business performance. The process of organizational decision in choosing strategies depend on organization capabilities in integrating asset strategy [26].

Palu city, the capital of Central Sulawesi province in Indonesia, produces natural rattan industry until 60 percent of national production. Huge rattan production encourage the development of rattan processing industry to process raw rattan into wicker rattan and rattan core and rattan furniture industry. Central Sulawesi province, especially Palu city, with all natural resources potential, has opportunities in foreign trade. Trade Balance of exports and imports rattan since the year 1997 to 2004 in these sectors continues to increase [31]. The amount of natural resources does not guarantee the industry performance improvement. Observations on performance degradation problem of rattan industry began to be felt in Indonesia in 2009, where data rattan exports in 2008 reached 76,000 tons, in 2009 decreased to 53,000 tons, and in 2010 rattan exports decline to 45,000 tons. It has an impact on local industry, specifically Palu city as main producer of rattan industry. Illustration of its financial performance in 2010 has decreased, with 43\% or 19 Rattan SMEs industry can not recover its production cost (loss). While 39\% or 17 rattan SMEs earn income from operations, and $18 \%$ or 8 Rattan SMEs industry can only refund the cost of its production (Break Even Point/BEP). Integration of intangible assets, competitive strategy and financial performance at rattan SMEs to be one interesting phenomenon for SMEs improvement and provide benefits to stakeholders. Integration is based on RBV concept, coupled with related theories, namely financial and strategy management, and based on empirical research results.

This study newness is specific financial performance measurement for SMEs, based on intangible asset investment strategy and competitive selections. In the previous studies have not found an explanation and a satisfactory answer. Measurement of intangible assets as individual variable, particularly relational capital, is done by adding an indicator, not only related to customer but to judge other stakeholders (suppliers, investors, government and associations), to refine the idea of research in complementary intangible assets measurement variables. Until now, has not been studied directly their effect on financial performance or mediation the determination and implementation of competitive strategy as an intervening variable in improving SMEs financial performance. Earlier reduction and compilation refers to grand RBV theory. Therefore, this study makes model integration of intangible assets, examine the indirect effects on financial performance as well as indirect effects mediated by strategies selection, both individual and comprehensive measurement.

\section{Literature Review And Conceptual Model}

RBV assumes that every organization/company is a collection of unique resources and capabilities that becoming basis of strategy and main source of company return. According to RBV perspective, the difference in performance is caused mainly by unique resources and company capabilities, not because of industrial structure 
characteristics [12]. In RBV context, resources are input to production process. Resources in the single form will not result a competitive advantage. Generally, competitive advantage achieved through combination and integration of a set of available resources.

The RBV is a method to analyze and identify a company's strategic advantage. It is based on a review the combination of assets, skills, capabilities, and intangible assets specific to an organization. The basic assumption of RBV fundamentally different. Every company has a "collection" unique resource of tangible and intangible assets and capabilities of organization to take advantage of these assets. Each company develops competencies from these resources. When well developed, this competence be a source of companies competitive advantage [32].

RBV basic reasons are the guide, type, amount and nature of a company's resources should be considered as first and foremost thing in choosing and setting strategies that can lead to sustainable competitive advantage. According to RBV, strategic management involves the development and exploitation of resources and unique company capabilities, and continuous efforts to maintain and strengthen various resources. This theory states that a company will gets a big advantage when running strategy that till not employed by any competitor. When other companies unable to duplicate a particular strategy, company has run sustainable competitive advantage. However, to get value, a resource should be rare, difficult to imitate and can not found easy replacement.

\subsection{Intangible Asset}

Perspective of intellectual capital originally developed as a framework for analyzing the contribution value of intangible assets in organization [33]. This perspective classifies as a human capital; organization capital; relationship and customer capital. Human capital consists of knowledge, skill, motivation and task capital. Organizational capital consists of business process and business \& development capital. Customer and relationship capital consists of customer relationship, supplier, partner network and capital investors relationship. Stewart [34] defines intellectual capital as intellectual material that has been standardized, captured, and leveraged to create wealth by producing a higher-valued asset. Furthermore, Lev [35] defines a nonprofit assets as "assets are claims to future benefits, such as the rents generated by commercial property, interest payment derived from a bond, and cash flow from production facility". Asset can fulfill rationale accounting criteria, skills and competencies intangible, including specific skills of employees, client, customer and organizational culture [2].

Intellectual capital is an organization resource that consists of human, structural and relational capital [36]. Human capital is defined at individual level as a combination of four factors: (1) your genetic inheritance, (2) your education, (3) Your experience, (4) Your attitudes about your life and business. Structural capital is a construct mechanisms and organizational structures that can help workers to use their intellectual ability to achieve business performance. Relational capital represented a potential source of intangible organizations at outside organization (ex-firm). Intangible resource includes knowledge of customers, suppliers, government, or industry-related associations.

The terminology of Intangible Assets, Intellectual Capital and Knowledge Assets are used interchangeable [35]. All the three are widely used: Intangible used in accounting literature, knowledge is used by economists, and intellectual capital used by management and legal literature. It is integration of "intangible assets" concept (especially in of accounting world) and "intellectual capital" (world of knowledge management and dynamic company based perspective) [15]. Perspective refers to same essence: a nonphysical claim to future benefits. This study uses "intangible asset" term. The reason is the grand theory derived from RBV theory, the elaboration of knowledge management strategy. It can be concluded that intangible assets / intellectual capital consists of human, organizational and relational capital [15,33,36,37,38].

OECD [39] defines Human Capital (HC) as individual knowledge acquired in their lifetime, and are used to produce goods, ideas or services at market or can not be sold. Choo and Bontis [36] defines HC as an inventory of organizational knowledge, as described by labor organizations or companies that combined to solve business problems. Furthermore, Daum [15] defines HC as a source of innovation and renewal, for new and good ideas created/produced by humans.

Organizational Capital (OC) is a resource owned by company, reflected in formal organizational structure clarity, planning, implementation and monitoring [12]. Definition OC as organizational structure associated with mechanisms and organizational structures that can support employees, to optimize performance, which in turn will improve organization performance [40]. Furthermore, Structural capital (organizational capital) measures the dimensions of competency-based infrastructure. It is operationalized as equipment used by company, in relation to the needs of information technology (IT) office [41]. It stated that company would have had a technological advantage SCA when compared with other companies, because the impact on the economical, efficient, effective and produce products according to customer requirements [42]. From the description above definition, Organizational capital or structural capital is knowledge assets within organization. 
It is produced through institutional knowledge, either individually or collectively during the learning process within company.

Relational Capital (RC) [43] is defined as the sum of resource potential available, and that existing relationships network in a person or social unit. Such relations explain relationship that can be applied to measure the connectivity and network hierarchy, mostly located in introductions network and mutual relations. The core dimensions of Relational Capital is company's relationship value with customer, suppliers, government, investors and associations, in terms of knowledge relating to company's external (stakeholder) [15, $33,36,44]$.

\subsection{Competitive Strategy}

Business strategy also known as competitive strategy. It focuses on improving competitive position of products and services in a particular industry or market segment served [18]. If company's strategy is to overcome the problem that served in business and industry, business strategy address how company and its units can compete in business and industry.

Porter offers three 'generic' competitive strategy for winning other companies in a particular industry: low-cost, differentiation, and focus [24]. Low cost strategy is ability of a company or a business unit to design, create and market a comparable product more efficiently than its competitors. Differentiation strategy is ability to provide unique or superior value to buyers in terms of quality, features / special features, or after-sales service. Strategy focus used by companies to select and focus the service on a particular group or weak competitors to be more efficient than competitor in broad market. This strategy is called generic because company with any type and size, even non-profit organizations, can use it.

\subsection{Financial Performance}

Financial performance is a measure of an organization's financial condition or financial outcomes resulting from management decisions and carried out by organization members [45]. The size of financial performance reflects the strategic decisions, operational and financing [46]. The analogy, finance is the heart of corporate, business strategy planning must be balanced by financial planning strategy. Any decision or business opportunity that taken should be adjusted according to calculations, weather it really profitable company or not [47].

Significant information in financial statements can be used to assess financial performance during a specific time [48]. It was concluded that financial Performance/PERF is part of financial statements which indicates the position of resource companies during the period, and financial statements describing financial company performance 's ability to generate revenue from its available resources [49].

SME financial performance measurement is done by comparing financial ratios. The goal is to see the weaknesses and strengths that have done an SME in running their business operations. Next time they will be able to make repairs and improvements in processing business in an attempt to obtain a good SME (healthy), a measure of perceived financial performance. Studies that measure SMEs financial performance generally consider revenue from sales, probfitability, sales growth and profit growth $[1,2,3,4,5,6,7,8,9,10,11]$.

Based on explanation above, this research is considered essential to be done. Research conceptual framework can be seen in Figure 1.

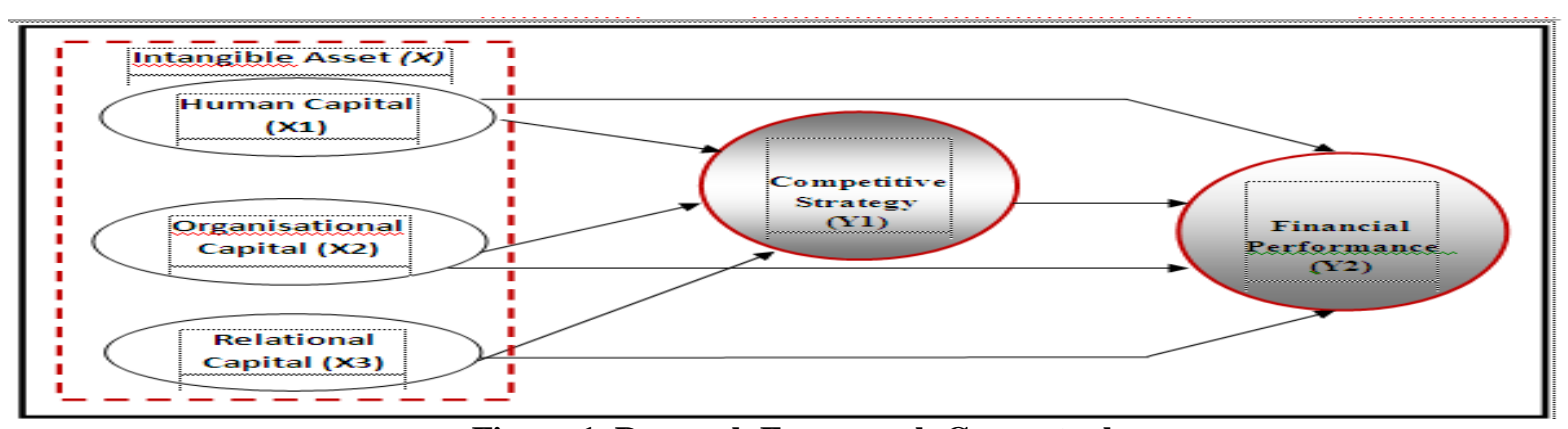

Figure 1. Research Framework Conceptual

\subsection{Research Hypothesis}

\subsubsection{Effect of Human Capital on Financial Performance}

Study conducted by Ulrich research program of OASIS (Organization and Strategic information Service) found a positive relationship between HR practices and business results [50]. Nahkata [51] found a positive relationship between human capital and financial performance. Other studies support a direct effect between human capital and company performance / financial performance $[2,10,43,52,53,54,55]$. 
Specifically, the study of Leitner [2] found elements of intangible asset. The innovation activities trend (human capital) is positively related to performance. Studies [56] generating partial measurements that knowledge (human capital) has no significant effect on SMEs performance. Similarly, studies [57] does not support effect the Learning and Growth on business performance. In this case, the manager or managers of SMEs businesses more rely on intuition [54].

Hypothesis 1 (H1): The higher investment in human capital, the higher SMEs financial performance

\subsubsection{Influence Organizational Capital on Financial Performance}

If company succeeds in developing and maintaining organizational learning (organizational capital), it was able to create intellectual capital that is difficult to imitate by competitors [58]. Learning can increase a company's ability to adapt and to respond quickly. Company produces a competitive advantage. Thus, the method and speed of organizational learning is the only sustainable source of competitive advantage [59].

Bontis [40] emphasized that organizational capital associated with mechanisms and organizational structures. It can support employees to optimize their performance and in turn will improve organizational performance / financial performance. Many studies support the direct influence between organizational capital on performance [10,15,54,60,61]. Specifically, the study Leitao [54] found the elements of the intangible asset, that is participatory and intensive management group meeting on organizational capital has no influence on nonfinancial performance achievement.

Hypothesis 2 (H2): The higher organizational capital investment, the higher SMEs financial performance

\subsubsection{Effect of Relational Capital on Financial Performance}

Relational capital is not only related to customer knowledge, but also knowledge that also deals with suppliers, governments, investors and relevant external parties to achieve a sustainable competitive advantage $[15,33,36,44]$. Furthermore Daum confirmed, to obtain value of external relations, company selects and invest in right asset to generate superior returns. Superior returns can be obtained if company can increase sales, one of them by building good relationships with stakeholders to achieve superior profits (profitability) $[10,15,62,63,64,65,66,67]$.

Hypothesis 3 (H3): The higher the relational capital investment, the higher SMEs financial performance

\subsubsection{Effect of Human Capital on Competitive Strategy}

Studies by Sampurno [22] states that alignment between HR and business strategy have an influence on company performance. Muchtolifah [68] explained that company's strategy resource derived from human resource capital. Human resources, in terms of formal education as well as knowledge and skills, affects the business management.

Research also supports that intangible element of assets (human capital) had no effect (low influence) on performance when not mediated by competitive strategy Porter [53,60,69,70,71].

Hypothesis 4 (H4): The higher investment in human capital, the more precise selection of SMEs competitive strategies

\subsubsection{Influence Organizational Capital and Competitive Strategy}

Edelman [72] said organizational capital or organization Resource can be measured through systems, policies, culture, knowledge organization, and routines and organizational structure. That indicator has no effect on performance if not mediated strategy. Pierre [11] found that SMEs that adopting different strategies will differ in regulating intellectual capital (Organizational capital). It adapted to particular way in order to achieve organizational performance.

Hypothesis 5 (H5): The higher organizational capital investment, the more precise selection of SMEs competitive strategies

\subsubsection{Effect of Relational Capital on Competitive Strategy}

If supplier reach and close to customer, it will have an impact on strategy. The purpose of business proximity and personal relationships is to establish "joint future", build a platform for "mutual dependence" and collective reward if successful. Help customer companies to thrive in business is an inexpensive way to strengthen company's growth. Model of business cooperation and mutual dependence strategic of customer relationships will generate higher value if customer also achieved economic success [73]. Research in marketing from Fang, Palmatier, and Grewal [74] showed that customer assets (capital relation) has a relationship to performance achievement when mediated by diversification strategy.

Hypothesis 6 (H6): The higher the relational capital investment, the more precise selection of SMEs competitive strategies 


\subsubsection{Effect of Competitive Strategy on Financial Performance}

Typology of business strategy is consistent with resource-based perspective, where VRIN criteria are a very fundamental aspect to achieve successful business strategy, especially to give value [23]. This means that company's strategy is an important part of company's organizational systems to improve business performance $[25,26,27]$. Studies $[28,29]$ specifically support the direct influence of the porter's competitive strategy and financial performance.

The study of Slater [25] asserts that strategic orientation of different ability elements will create strategies and performance. Musyarofah study [75] demonstrated, the budgeting type are not moderate relationship between strategy and organizational performance. Company's performance can be achieved if company has a competitive advantage compared to other companies. Competitive advantage generated by the precision of strategies chosen and implemented by company.

Hypothesis 7 (H7): The more precise selection and implementation of competitive strategy, the higher SMEs financial performance

\subsection{Population and Research Sample}

\section{Research Methods}

Population studies are all manufacturing SMEs that produce rattan products, typical products of Central Sulawesi such as rattan furniture and handicrafts. Rattan SME population in Palu city amounted to 44 SMEs. There and 38 viable SMEs can be analyzed the data. Therefore, it done study entire population (samples saturated), census study. Sample unit is 38 Rattan SMEs in Palu city. The analysis unit is rattan SMEs. respondent is company owner or manager.

\subsection{Data Collection and Analysis Methods}

This study collected data from primary and secondary sources. Secondary data was collected from the Department of Industry and Trade in Palu city, Central Sulawesi and the BPS. Primary data was collected through research instruments (questionnaires) and in-depth interviews. Measurement data in this study using a Likert scale. Each item is assessed on a Likert scale scoring. The interval range from 1 (Strongly Disagree-SD), 2 (Disagree-D), 3 (Neutral-N), 4 (Agree-A) and 5 (Strongly Agree-SA). Data analysis in this study use descriptive and inferential statistics PLS (Partial Least Square)

\subsection{Validity and Reliability Testing}

All indicators on each variable has the outer loading $>0.50$ and is also significant (p-value), so the research instrument is valid for all variables, as shown in Table 1.

Table 1

Outer Loading for Every Indicators

\begin{tabular}{|l|c|c|}
\hline \multicolumn{1}{|c|}{ Variable and Indicator } & $\begin{array}{c}\text { Original sample } \\
\text { estimate }\end{array}$ & p-value \\
\hline Human Capital (X1) & & \\
\hline Education (X1.1) & 0.856 & 0.000 \\
\hline Skill (X1.2) Organizational Capital (X2) & 0.870 & 0.000 \\
\hline Ability (X1.3) & 0.830 & 0.000 \\
\hline \multicolumn{1}{|c|}{ Relational Capital (X3) } & 0.915 & \\
\hline Structure \& Organization Governance (X2.1) & 0.813 & 0.000 \\
\hline Management Procedure (X2.2) & 0.833 & 0.000 \\
\hline Technology (X2.3) & & \\
\hline & & 0.840 \\
\hline Relationship with Partner (X3.1) & 0.861 & 0.000 \\
\hline Relationship with Supplier and Customer (X3.2) & 0.863 & 0.000 \\
\hline Relationship with Investor and Government (X3.3) & & \\
\hline Competitive Strategy (Y1) & 0.871 & 0.000 \\
\hline Leadership Cost Strategy (Y1.1) & 0.898 & 0.000 \\
\hline Differentiation Strategy (Y1.2) & 0.864 & 0.000 \\
\hline Focus Strategy (Y1.3) & & 0.000 \\
\hline Financial Performance (Y2) & 0.848 & \\
\hline Sales (Y2.1) & & 0.000 \\
\hline Profitability (Y2.2) & & \\
\hline Growth (Y2.3) & & \\
\hline Source: Adapted from primary data & \\
\hline
\end{tabular}

Source: Adapted from primary data 
Indicators that measure the latent variable have good reliability if the composite value $>0.70$. The test results in Table 2 show that all research instrument is reliable, because it has composite reliability value $>0.70$.

Table 2

Instrument Reliability Testing Results

\begin{tabular}{|l|c||c|}
\hline \multicolumn{1}{|c|}{ Variables } & Composite Reliability & Description \\
\hline X1 (Human Capital) & 0.888 & Reliable \\
\hline X2 (Organizational Capital) & 0.891 & Reliable \\
\hline X3 (Relational Capital) & 0.891 & Reliable \\
\hline Y1 (Competitive Strategy) & 0.910 & Reliable \\
\hline Y2 (Financial Performance) & 0.912 & Reliable \\
\hline
\end{tabular}

Source: Adapted from primary data

Model in this study is said fit if supported by empirical data. Good of fit in structural models analysis in PLS, predictive-relevance $\left(\mathrm{Q}^{2}\right)$ value, is calculated based on $\mathrm{R}^{2}$ value for each dependent variable. Predictiverelevance $\left(\mathrm{Q}^{2}\right)$ value in this research is at 0.9879 or $98.79 \%$. This means that model can explain the phenomena associated with financial performance of some variables studied (human capital, organizational capital, relational capital and competitive strategy) of $98.79 \%$. Therefore, this model can be said to be very good, or model has a very good predictive value. Finally, the model can be used for hypothesis testing.

\section{Results And Analysis}

Research results showed the indicator of outer loading is strongest variable (dominant), or can be interpreted as the most important indicator. The mean value indicates the actual condition of each indicator, according to responden judgment or perception.

Table 3

Outer Loading and Mean value of each indicator of each variable

\begin{tabular}{|c|c|c|c|}
\hline Variable & Indicator & Outer Loading & Mean \\
\hline \multicolumn{4}{|c|}{ Human Capital (X1) } \\
\hline & X11 (Knowledge) & 0.856 & 3.59 \\
\hline & X12 (Skill) & 0.870 & 3.82 \\
\hline & X13 (Ability) & 0.830 & 3.89 \\
\hline \multicolumn{4}{|c|}{ Organizational Capital (X2) } \\
\hline & X21 (Structure \& Organization Governance) & 0.915 & 3.61 \\
\hline & X22 (Management Procedure) & 0.813 & 3.86 \\
\hline & X23 (Technology) & 0.833 & 3.53 \\
\hline \multicolumn{4}{|c|}{ Relational Capital (X3) } \\
\hline & X31 (Relationship with Partner) & 0.840 & 3.79 \\
\hline & X32 (Relationship with Supplier and Customer) & 0.861 & 3.73 \\
\hline & X33 (Relationship with Government \& Investor) & 0.863 & 3.53 \\
\hline \multicolumn{4}{|c|}{ Competitive Strategy (Y1) } \\
\hline & Y11 (Cost Leadership Strategy) & 0.871 & 3.49 \\
\hline & Y12 (Differentiation Strategy) & 0.898 & 3.92 \\
\hline & Y13 (Focus Strategy) & 0.864 & 3.49 \\
\hline \multicolumn{4}{|c|}{ Financial Performance (Y2) } \\
\hline & Y21 (Sales ) & 0.941 & 3.63 \\
\hline & Y22 (Profitability) & 0.849 & 3.37 \\
\hline & Y23 (Growth) & 0.848 & 3.36 \\
\hline
\end{tabular}

Source: Adapted from primary data 
Data in Table 3 show the human capital variables has skill as most dominant indicator, outer loading is 0.870 , greater than knowledge (0.856) and capability (0.830). But in reality, it is not used as a primary consideration in Rattan SMEs . This is indicated by low mean value (3.82). The evidence suggests that SMEs managers ability is more important (3.89) than knowledge and skills. Organizational capital variable inform, the most dominant indicator is organizational structure and governance, with outer loading 0.915 , larger than management procedure $(0.813)$ and technology $(0.833)$. But in reality, it is not used as a primary consideration in Rattan SMEs. This is indicated by low mean values (3.61). The fact shows, SME management procedures more important (3.86) than organizational structure and governance and technology.

Relational capital variables inform the dominant indicator is relationship with government and investors, outer loading value 0.863 is greater than relationships with partners $(0.840)$, and relationships with suppliers and customers (0.861). In fact, it would not be a major consideration in Rattan SMEs . This is indicated by low mean values (3.53). The fact more perceive that relationship with SMEs partner are more important (3.79) than relationships with suppliers, customers, government and investors. Competitive strategy variable informs, the dominant indicator is a differentiation strategy, outer loading 0.898 greater than cost leadership strategy (0.871) and focus strategy (0.864). This fact is same with considerations in Rattan SMEs, this is indicated by the highest mean value (3.92), cost leadership strategy (3.49) and focus strategy (3.49). This indicates that indicators are considered important in measuring the implementation of competitive strategy, same as the realization of Rattan SMEs in Palu city, the differentiation strategy. Inform financial performance variables, indicators of the dominant or most important is sales, with outer loading values greater than 0941 profit $(0.849)$ and growth $(0.848)$. The fact that same considerations take precedence in SMEs rotan. It is indicated by the highest mean value (3.63), followed by profit (3.37) and growth (3.36). This indicates the indicators are important in financial performance measurement. It is same as the realization of the activities of Rattan SMEs in Palu, ie applying the income from sales.

Hypothesis testing result of direct effect between the variables of human capital, organizational capital, relational capital, competitive strategy and financial performance has been done. Of the seven direct effects tested, there were five significant influence, namely: organizational capital variables has significant effect on financial performance variables, human capital variables has significant effect on competitive strategy variables, organizational capital variables has significant effect on competitive strategy variables, relational capital variables has significant effect on competitive strategy variable and competitive strategy variables has significant effect on financial performance variables. Human capital variable has insignificant effect on financial performance variables and relational capital variables has insignificant effect on financial performance variables

Table 4

The Direct Effect Analysis Results

\begin{tabular}{|l|c|c|c|}
\hline \multicolumn{1}{|c|}{ Variable Relationship } & $\begin{array}{c}\text { Path } \\
\text { Coefficient }\end{array}$ & p-value & Description \\
\hline Human Capital (X1) -> Financial Performance (Y2) & 0.043 & 0.728 & Nonsignificant \\
\hline Organizational Capital (X2) -> Financial Performance (Y2) & 0.407 & 0.000 & Significant \\
\hline Relatioanal Capital (X3) -> Financial Performance (Y2) & 0.021 & 0.562 & Nonsignificant \\
\hline Human Capital (X1) -> Competitive Strategy (Y1) & 0.063 & 0.013 & Significant \\
\hline Organizational Capital (X2) -> Competitive Strategy (Y1) & 0.785 & 0.000 & Significant \\
\hline Relatioanal Capital (X3) -> Competitive Strategy (Y1) & 0.134 & 0.000 & Significant \\
\hline Competitive Strategy (Y1) -> Financial Performance (Y2) & 0.501 & 0.000 & Significant \\
\hline
\end{tabular}

Significant at .05 level $(p$-value $\leq 0,05)$

The test results in Table 4 shows that path coefficient of direct effect between human capital variables (X1) with financial performance variables (Y2) generates path coefficient 0.043 and a p-value of 0.728 . These results indicate that first hypothesis (H1), which states the higher investment in human capital, the higher financial performance, is rejected. However, the positive path coefficient means that relationship between human capital and financial performance is unidirectional. This means the higher investment in human capital, the higher Rattan SMEs financial performance, although the unidirectional relationship is insignificant.

The analysis result of direct influence between organizational capital (X2) and financial performance (Y2) generates path coefficient 0.407 and p-value 0.000 . These results suggest that second hypothesis (H2), which states the higher investment in organizational capital, the higher SMEs financial performance, is accepted. Positive path coefficient indicates that relationship between organizational capital and SMEs financial 
performance is unidirectional. The unidirectional relationship suggests that organizational capital investments can improve Rattan SMEs financial performance.

Test results between relational capital variable (X3) and financial performance (Y2) generates path coefficients 0.021 and p-value 0.562 . These results indicate that third hypothesis (H3), which states the higher relational capital investment, the higher SMEs financial performance, is rejected. However, the positive sign of path coefficient means that relationship between relational capital and financial performance is unidirectional. This means the higher relational capital investment, the higher Rattan SMEs financial performance, although relationship insignificant in this study.

Analysis results of direct influence between human capital (X1) with competitive strategy (Y1) generates path coefficients 0.063 and p-value 0.013 . These results indicate that fourth hypothesis (H4), which states the higher investment in human capital then more precise selection of SMEs competitive strategies, is accepted. Positive path coefficient indicates that human capital investment improve the precision and execution of SMEs competitive strategies.

Analysis results of direct influence between organizational capital (X2) with competitive strategy (Y1) generates path coefficients 0.785 and p-value 0.000 . These results suggest that fifth hypothesis (H5), which states the higher investment in organizational capital, the more precise selection of SMEs competitive strategies, is accepted. Positive path coefficient indicates that organizational capital investments improve the precision and implementation of SMEs competitive strategies.

Analysis results of direct influence between the relational capital (X3) with competitive strategy (Y1) generates path coefficient 0.134 and p-value 0.000 . These results indicate that sixth hypothesis (H6), which states the higher the relational capital investment, the more precise selection of SMEs competitive strategies, is accepted. Positive path coefficient indicates that relational capital investment can increase the selection precision and implementation of SMEs competitive strategies.

Analysis results of direct influence between competing strategies (Y1) and financial performance (Y2) generates path coefficient 0.501 and p-value 0.000 . These results suggest that hypothesis seven $(\mathrm{H} 7)$, which states the more precise selection of competitive strategy, the higher SMEs financial performance, is accepted. Positive path coefficient indicates that relationship between competitive strategy and SMEs financial performance is unidirectional. Unidirectional relationship suggests that competitive strategy can improve Rattan SMEs financial performance. Hypothesis test results are presented in Figure 3.

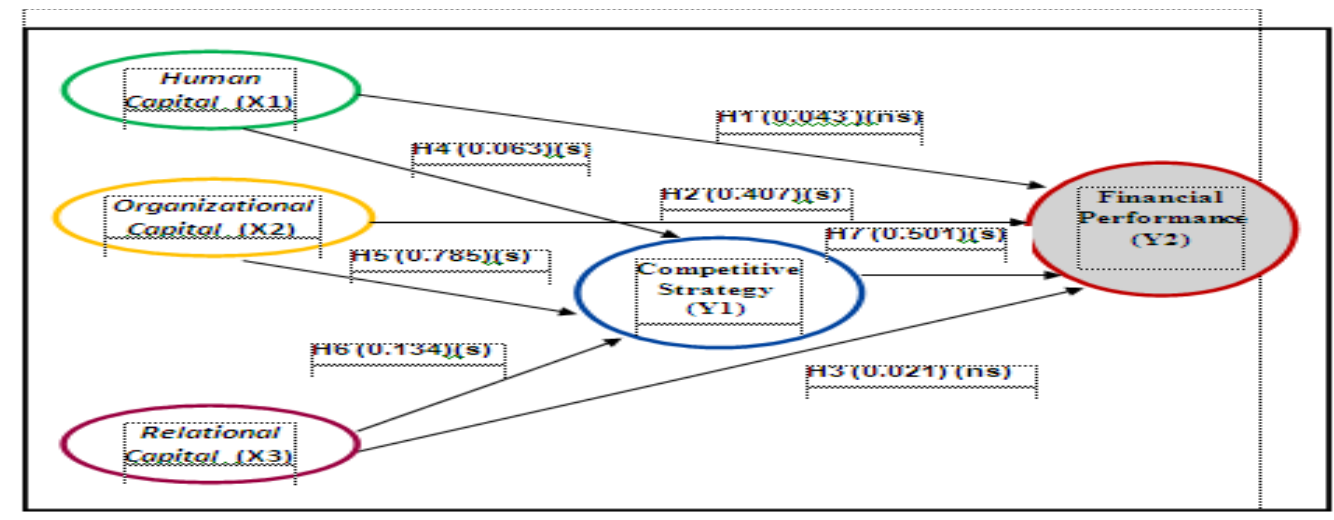

Figure 2. Result Testing of Path Diagram Hypothesis Description: s (significant path), ns (nonsignificant paths)

Indirect testing aims to determine the result of mediation variable, weather complete or partial mediation. Result of indirect effect (mediating variable) is used to justify whether a model based on RBV theory can be accepted or not. Testing is done as follows:

Table 5

Analysis of Mediation Test Without Competitive Advantage Variables

\begin{tabular}{|l|c|c|c|}
\hline \multicolumn{1}{|c|}{ Variable Relationship } & $\begin{array}{c}\text { Path } \\
\text { Coefficient }\end{array}$ & p-value & Description \\
\hline Human Capital (X1) -> Financial Performance (Y2) & 0.792 & 0.000 & Complete Mediation \\
\hline Organizational Capital (X2) -> Financial Performance (Y2) & 0.932 & 0.000 & Partial Mediation \\
\hline Relatioanal Capital (X3) -> Financial Performance (Y2) & 0.736 & 0.000 & Complete Mediation \\
\hline
\end{tabular}

Source: Adapted from primary data 
Table 5 shows the standardized tests to determine the position of mediation. The indirect effect of human capital on financial performance through competitive strategy is complete mediation. These results indicate the higher human capital investment, mediated by selection competitive strategy, the higher SMEs financial performance. This study shows that human capital can not directly improve financial performance, financial performance can be achieved when mediated by the execution of competitive strategy. The indirect effect of organizational capital on financial performance, through competitive strategy, is partial mediation. These results indicate the higher organizational investment capital, mediated by selection of competitive strategy, the higher SMEs financial performance. Indirect effect relational capital on financial performance, through competitive strategy, is complete mediation. These results indicate the higher relational capital investment, mediated by selection competitive strategy, the higher SMEs financial performance. Relational capital can not directly improve SMEs financial performance. This can be achieved when mediated by the implementation of competitive strategy. The testing does not directly produce a integration model of "intangible assets, competitive strategy and financial performance", meaning RBV theory applies in this study.

\section{Discussion}

Analysis the influence of human capital on SMEs financial performance is no significant (H1). This means the higher human capital investment can not increase SMEs financial performance [2,54,56,57]. This study result are not consistent with previous studies [10,43,50,51, 52, 53, 54, 55]. Leitner [2] found that element of human capital, with the tendency to innovate, does not improve performance. Ardiana [56] conducted a partial measurement. The results showed elements of human capital (knowledge) can not improve performance. Here, the manager or managers of SME businesses more rely on intuition [54]. Chaichan [57] showed that an increase in Learning and Growth can not increase business performance. Inconsistency of results may be caused by differences in selection of study sites and different instruments.

Model studies have shown the influence of human capital on financial performance mediated by competitive strategy. Results show that human capital has an indirect effect on financial performance, through competitive strategy. The indirect effect of human capital through competitive strategy on financial performance is categorized as complete mediation. That is, human capital has an influence on competitive strategy and competitive strategy affect financial performance, but human capital has no direct impact on financial performance. Therefore, the perfectly competitive strategies can mediate between human capital on financial performance.

Analysis result the influence of organizational capital on SMEs financial performance show a significant effect $(\mathrm{H} 2)$. This means the higher investment in organizational capital, the higher Rattan SMEs financial performance. Results of this study are consistent with research that supports the direct influence between organizational capital performance $[10,15,54,60,61]$.

Analysis result the influence of organizational capital on financial performance is mediated by competitive strategy. Results show that organizational capital has a direct impact on financial performance and competitive strategy. The indirect effect of organizational capital through competitive strategy on financial performance is classified as incomplete mediation. That is, organizational capital has an influence on competitive strategy and financial performance, and competitive strategy affect financial performance. Therefore, directly or indirectly, human capital has an influence on financial performance. Competitive strategy only partially mediate the influence of human capital on financial performance.

Analysis result the influence Relational capital show no significant effect on SMEs financial performance (H3). This means investment in relational capital can not increase SMEs financial performance. Results of this study are not consistent with research that states that superior returns can be obtained if company can increase sales (sales), one with a good relationship with stakeholders, superior profits (profitability) can be achieved $[10,15,62,63,64,65,66,67]$.

Influence of relational capital on financial performance is mediated by a competitive strategy. Results showed that relational capital has an indirect effect on financial performance through competitive strategy. Indirect effect the relational capital through competitive strategy on financial performance is categorized as complete mediation. That is, relational capital affect competitive strategy and competitive strategy affect financial performance. But directly, relational capital does not have any effect on financial performance. Therefore, the competitive strategies can mediate the relational between capital effects on financial performance.

Human capital investment is not significant and can improve financial performance if not integrated with the implementation of competitive strategy. These results are consistent with concept of human capital that are designed to ensure that people with right capabilities are placed at right place to execute strategy [22]. Analysis results the influence of human capital to SMEs competitive selection strategies showed a significant effect (H4). This means the higher investment in human capital, the more precise selection of SMEs competitive 
strategies. Human capital can not directly improve financial performance, but can indirectly improve financial performance when mediated competitive strategy.

Results showed that organizational capital affect competitive strategy (H5). It explains the higher capital investment, the more precise organizational strategy selection. Organizational capital can directly improve financial performance, and indirectly will improve financial performance when mediated competitive strategy. This study is consistent with research conducted by Edelman [72] and Pierre [11]. Edelman [72] to obtain result that capital or resources in an organization can be measured through the system, policy, culture, knowledge organization, and routines and organizational structure to improve financial performance. Research from Pierre [11] found that SMEs are adopting different strategies will be different in regulating intellectual capital (Organizational capital) in accordance with a certain way to achieve organizational performance. This study is consistent with research of Virjande Santos [76]. The study was conducted on a medium business in Spain. Results show Organizational capital influence on selection strategy. Furthermore, the research is consistent with Pierre [11] who found that SMEs are adopting different strategies will differ in regulating intellectual capital (Organizational capital), adapted to a particular way to achieve organizational performance.

Relation capital has a direct influence on selection of competitive strategy (H6). Relational capital investment is meaningless and can not improve financial performance if not integrated with the implementation of competitive strategy. That is a very strong relationship with resources is needed to establish and implement strategies. Results showed that relational capital affect competitive strategy selection. It explains the higher relational capital investment, the more precise selection strategy. Relational capital can not directly improve financial performance, but can indirectly improve financial performance when mediated competitive strategy.

Analysis result the influence of competitive strategy on SMEs financial performance showed a significant effect (H7). Results shows that competitive strategy affect financial performance. It explains the more precise competitive strategy selection, the higher Rattan SMEs financial performance [25,26,27]. Particularly, studies [28, 29] supports the direct influence of the porter's competitive strategy on financial performance. Results of this study indicate that most dominant strategy affecting financial performance is differentiation [76]. These results contrast with studies Amoako \& Acquoah [70], where the implementation of competitive strategy has no effect on corporate performance.

\subsection{Theoretical Implications}

\section{Research Implications}

Research results prove the direct influence of human capital on competitive strategy, organizational capital on competitive strategy and financial performance, relational capital on competitive strategy and financial performance. Meanwhile, the indirect effect mediated by competitive strategy provides evidence that variables of intangible assets (human capital, organizational capital and relational capital) can increase performance when mediated by a competitive strategy. It can develop knowledge of financial management and strategic management.

Measurement of financial performance using perceptual information can be mined in SMEs finance. It can provide new insights for subsequent researchers. Furthermore, organizational capital more influence on financial performance improvement, either directly or mediated competitive strategy, drawn from a larger path coefficients. The role of organizational capital describes SMEs that apply organizational structure to affects the clarity of its duties and functions. This is done by building accountability, transparency and efficiency through organizational governance; management procedures through planning, execution and control, and respond to new technology usage is considered very important to improve Rattan SMEs financial performance Palu. It is clear that organizational capital associated with mechanisms and organizational structures that can support employees to optimize their performance, which in turn will improve organizational performance / financial performance [40]

Empirical results in line with concept of Resources-Based View (RBV). Integration of intangible assets, competitive strategy achieve optimal performance. This means that financial performance will increase when mediated by a competitive strategy. In other words, the sales level, profitability and growth of SMEs acquisition will be greater when mediated by a competitive strategy. Expected integration model in this study proved.

\subsection{Practical Implications}

This study provides evidence that organizational capital can directly improve financial performance. But the fact on Rattan SMEs in Palu show that having intangible assets of human capital and relational capital has not applied optimally, so it can not directly improve financial performance. Important activity in human capital is related to knowledge of the training, production skills and ability to lead. Relational capital is needed to build relationships through sharing between business partners; long-term relationships with suppliers and government relations involving SME policies. 
Managers can make a differentiation strategy as SMEs key strategies, but still have to pay attention to the cost of leadership strategy and focused strategy. On activity in determining the selling price, company should implement a cost leadership strategy, with emphasis on production cost, more efficient process. On the product marketing activities, strategic focus is an important strategy to be applied to market the product according to the market segment. Selection of competitive strategy based qualification proves that intangible assets that meet the concept of RBV VRIN can impact on increasing sales of rattan products, as a measure of financial performance.

Since the enactment the ban of raw rattan export in January 1, 2012, the national rattan industry is required to produce finished goods. To increase sales and profitability, every SME should have a differentiation strategy in producing rattan quality, useful products, various products and products with exceptional service. In addition, Rattan SMEs Palu does not leave cost focus strategies related to the acquisition of raw materials, production cost efficiency, affordability, and leadership strategies, related to market segmentation and consumer needs. This means that, in implementing competitive strategy of Rattan SMEs Palu integrate these Porter strategies.

This study provides information to government as policy makers about importance of intangible assets investment which are basis for determining competitive strategy (business strategy) to achieve more optimal Rattan SMEs financial performance, controlling for external factors in future that internal factors prepared for Developing Rattan SMEs in Palu.

\section{Conclusion}

Generally, results of this study indicate that Rattan SMEs financial performance in Palu is neutral (medium). Financial performance can be achieved optimally when intangible assets qualifications is increased. Optimization of intangible assets consist of improvement of human capital qualification, increasing the organizational capital qualification and qualification of relational capital improvement. Financial performance is influenced by intangible assets and also mediated by precise selection of competitive strategy.

Particularly, results of hypothesis testing can be concluded follows. First, there was no direct effect the increase in human capital investment on financial performance improvement. Second, there is direct effect of increased investment capital on the increase of organizational financial performance. Third, there is no effect of increasing investment in relational capital to improving financial performance. Results of this study confirm that intangible asset investment decisions of owners/managers are influenced by differences in human capital qualifications, organizational capital and relational capital. Empirical evidence has implications that the financial performance differences due to differences in qualification of organizational capital. Fourth, human capital directly affects the competitive strategy selection. Fifth, organizational influence on the competitive strategy selection. Sixth, relational capital affect competitive strategy. Seventh, competitive strategy affect financial performance. Results of this study confirm that owner/manager, in selecting a competitive strategy, influenced by differences in intangible assets qualifications (human, organizational and relational capital) and resulting difference in achieving financial performance. This empirical evidence implies that only a portion of intangible assets affect financial performance. Financial performance will be increased maximally when reinforced with competitive strategy election. This means when intangible assets qualification can not improve financial performance, the owner/manager must choose right strategy to expand its business.

There are several limitations to this study. Research object only Rattan SMEs industry in Palu city, the respondent are owners/managers of Rattan SMEs . Thus, these findings may limit the generalizability of this study to manufacturing SMEs in other areas. Furthermore, the empirical study analysis is based on crosssectional survey data. Because of competition and business environment is constantly changing, it is necessary to know the change in future research and to reexamine whether relationship between the variables analyzed in this study will change.

Recommendations for subsequent research model are follows. Due the research is limited on Rattan SMEs industry in Palu city, the next study is expected to research another manufacturing SMEs that becoming main commodities in their region. This research is expected to inspire and encourage empirical research related to financial research that using perception measurement to Small and Medium Enterprises (SMEs), which is relatively rare. Subsequent research model can be developed to explore the cognitive style (analysis and intuition) to enrich investment in intangible assets to determine competitive strategy and improve financial performance.

\section{References}

[1] Bijmolt, T.H.A. and Zwart, P.S., The impact of internal factors on the export success of dutch small and medium-sized firms, Journal of Small Business Management, ProQuest 69, 32(2), Apr 1994

[2] Leitner, K., Intangible resources and firm performance: Empirical evidence from Austrian SMEs, Paper prepared for the 16th Nordic Academy of Management Meeting Uppsala, 16th $-18^{\text {th }}$, August 2010 
[3] Aragon-Sanchez, A. and Sanchez-Marin, G., Strategic orientation, management characteristics, and performance : A study of Spanish SMEs, Journal of Small Business Management, 43(3), 2005, 287-308

[4] Parera, S. and Baker, P., Measure for measure, SMEs Get the idea (Dossier Small Business, 2005)

[5] Johnsen, P.C. and Mcmahon, R.G.P., Cross-industry differences in SME financing behaviour: an Australia perspectiv, Journal of Small Business and Enterprise Development; 12(2), 2005,160

[6] Shoobridge, G.E., Multi-Ethnic workforce and business performance: Review and synthesis of the empirical literature, Human resource development review, 5(1), Maret 2006, 92

[7] Hirobumi, T. and Tanaka,Y., Entrepreneurial orientation and business performance of small and medium scale enterprises of Hambantota District Sri Lanka, Asian Social Science, 6(3), 2010

[8] Camison, C. and Villar-Lopez, Effect of SME's international experience on foreign intensity and economic performance: The mediating role of internationally exploitable assets and competitive strategy, Journal of Small Business Management. 48(2), 2010, $116-151$

[9] Ho, G.T.S. and Choy, K.L., An examination of strategies under the financial Tsunami, Industrial Management \& Data Systems, 110 (9), 2010, 1319-1336

[10] Sharabati, A.A., Shawqi, N.J., and Bontis, N., Intellectual capital and business performance in the pharmaceutical sector of Jordan, Management Decision, 48(1), 2010, 105-131

[11] Pierre, J.S., Intangible assets and performance analysis on manufacturing SMEs, Journal of Intellectual Capital, 12(2), 2011, 202223

[12] Barney, J., Firm resources and sustained competitive advantange, Management Scince, 17, 1991, 99-120

[13] Grant, R.M., Contemporary strategy analysis $\left(7^{\text {th }}\right.$ Edition John Wiley \& Sons, Ltd., 2010)

[14] Hitt , M.A,. R.D., Ireland and R.E., Hoskisson., Strategic management: Competitiveness and globalization: Concepts. (Ninth Edition, South-Western Cengage Learning, USA 2011)

[15] Daum, J.H., Intangible assets-based enterprise management - a practical approach, This paper has been presented at the PMA IC Symposium, Stern School of Business, New York University, (Online) Available ,at http://www.juergendaum.com/news/01_15_2006.htm, NYC/USA 2005

[16] Rumelt, R., Towards a strategic theory of the firm, in R. Lamp (Ed), Competitive strategic management (Englewood Cliffts, NJ: Prentice-Hall, 1984) 556-570

[17] Wernerfelt, B., A Resource-based view of the Firm, Strategic Management Journal, 5, 1984, 171- 180

[18] Wheelen, L.T., and Hunger, J.D., Manajemen strategis (Penerbit Andi, Yogyakarta 2001)

[19] Villalonga, B., Intangible resources and the sustainabilty of competitive advantange (Harvard Business Scholl, Boston: MA, 2002)

[20] Barney, J., Looking inside for competitive advantage, Academy of Management Executive, 9, 1995, 49-61

[21] Teece, D.J., Pisano, G. and Shuen, A., Dynamic capabilities and strategic management. Strategic Management Journal, 18(7), 1997, 509-533

[22] Sampurno, Manajemen Strategik: Menciptakan keuanggulan bersaing yang berkelanjutan (Penerbit UGM, Yogyakarta 2010)

[23] Panrell. J.A., Generic strategies after two decades: a reconceptualization of competitive strategy, Management Decision, 44 (8), 2006, 1139-1154

[24] Porter, M.E., Strategi sersaing. Tehnik menganalisis industri dan pesaing (Erlangga, Jakarta 1993)

[25] Slater, S.F., Olson, E.M., and Hult, G.T., Research notes and commentaries The moderating influence of strategy formation capability - performance relationship, Strategic Management Journal, 27, 2006, 1221-1231

[26] Sulastri, Sebuah pengembangan model hipotesis pengaruh aset strategis dan lingkungan terhadap pilihan strategi diversivikasi, Jurnal Manajemen \& Bisnis, 4(7), 2006

[27] Muafi, Pengaruh derajat kesesuaian orientasi strategi, lingkungan eksternal,struktur saluran ekspor, budaya organisasi dan kinerja ekspor. Jurnal Manajemen dan Kewirausahaan, 10(2), 2008, 153-162

[28] Yamin, S., Gunasekaran, A., and Mavondo, F.T., Relationship between generic strategies, competitive advantage and organizational performance: an empirical analysis, Technovation, 19, 1999, 507-518

[29] Finney, R.Z and Lueg, J.E., Market pioners, late movers, and the Resources-Based View (RBV): a conceptual model, Journal of Business Reseach, JBR-06526, 8, 2007

[30] Jauch, L.R, and Gluech, W.F., Strategy management and business policy (McGraw Hill, Inc., 1995)

[31] Posted, Menggagas kota industri. Available at http://investasipalu.wordpress.com/2007/11/05/menggagas-kota-indstri/, 5 november 2007

[32] Peace II, J.A., Robinson J., and Richard, B., Manajemenn strategi - formula, implementasi, dan pengendalian (Edisi 10, Buku 1, Salemba Empat, Jakarta 2011)

[33] Roos, G., and J. Roos., Measuring your company’s intellectual performance, Long Range Planning, 30(3), 1997, 325

[34] Stewart, T.A., Intelectual capital: The new wealth of organizations (Doubleday/Currency, Available at http://www.intellectualcapital.com, New York 1997)

[35] Lev, B., Intangible: Management, measurement and reporting (Brookings Institution. Washinton DC, Available at www.brookings.edu, http://207.87.9.12./html/charts/99FEseei-2.html, 2001)

[36] Choo, C.W., and Bontis, N., The strategic management of intellectual capital and organizational knowledge (Oxpord University Press, New York 2002)

[37] Edvinsson and Malone, Intellectual capital: realizing your company's true value by finding brainpower (Harper Collins, New York 1997)

[38] Sveiby, K.E., The new organizational wealth: Managing and measuring knowledge based asset (Barrets Koehler, San Fransisco, CA,1997)

[39] OECD, Measuring what people know: Human capital accounting for the knowledge economy, Paris 1996

[40] Bontis, N., Intellectual capital: an exploratory study that develops measures and models. Management Decision, 36(2), 1998, 63

[41] Pablos, P.O., Intellectual capital reporting in Spain: a competitive view, Journal of Intellectual Capital, 4(1), 2003

[42] Purwohandoko, Integrasi sumberdaya internal dan orientasi pasar sebagai basis strategi bersaing pada perusahaan Air Minum Dalam Kemasan (AMDK) di Jawa Timur. Malang, Disertasi Fakultas Ekonomi Unibraw, Unpubliced, 2009

[43] Coleman, J.S., The role of human and financial capital in the profitability and growth of women-owned small firms, Journal of Small Business Management, 45(3), 2007, 303

[44] Sasono, A.D., Intellectual capital: Alternatif strategi dalam era globalisasi untuk meningkatkan performance, Malang, Disertasi Fakultas Ekonomi, Universitas Brawijaya, Unpublicated, 2008 
[45] Carton, R.B., and Hofer, C.B., Measuring organizational performance: Metrics for entrepreneurship and strategic management meseach (Edward Elgar Publishing, Inc., USA 2006)

[46] Weston, J.F., and Copeland, T.E., Manajemen keuangan. Jilid 1 (Bina Rupa Aksara, Tanggerang 2010)

[47] Sadeli, F., Liku-liku strategi keuangan perusahaan: Panduan praktis meningkatkan nilai perusahaan (Salembe Empat, Jakarta 2011)

[48] Andreas, Manajemen keuangan UKM (Graha Ilmu, Yogyakarta 2011)

[49] Darsono and Ashari, Pedoman praktis memahami laporan keuangan (Penerbit Andi, Yogyakarta 2005)

[50] Ulrich, D., A. Geller and G. DeSauza, A strategy, structure, human resources database: OASIS, Human Resources Management, 14 , 1984, 77-90

[51] Nakhata, C., The effects of human capital and entrepreneurial competencies on the career success of SME entrepreneurs in Thailand. The Business Review, Cambridge, 9(1), 2007, 62

[52] Murphy, T.E., and Zandvakili, S., Data-and metrics-driven approach to human resources practices: Using customers, employees, and financial metrics. Human Resources Management, 39(1),2000, 93-105

[53] Hitt, M.A., Bierman, L., Shimizu, K., and Kochhar, R., Direct and moderating effects of human capital on strategy and performance in professional service firms: A Resource-Based Perspective. Academy of Management Journal, 44(1), 2001, 13-28

[54] Leitão J., and Franco, M., Individual entrepreneurship capacity and performance of SMEs University of Beira Interior. Available at http://mpra.ub.uni muenchen.de/8179/MPRA Paper No. 8179, 09 April 2008

[55] Chio, Y.C., Internationalization, Intangible asset, \& Taiwan SMSs performance : Evidence of an Asian NIE's (Newly-Industrilized Economy). African Journal Of Business Management, 5(3), 2011, 641-655

[56] Ardiana, I.A., Brahmayanti and Subaedi, Kompetensi SDM UKM dan Pengaruhnya Terhadap Kinerja UKM di Surabaya. Jurnal Management dan Kewirausahaan, 12(1), 2010, 42-55

[57] Chaichan, C., and Chansa-ngavej, C., Intangible asset management framework : an empirical evidence industrial management \& data systems. School of Management. Shinawatra University SIU International. Bangkok, Thailand, $110(7), 2010,1094-1112$

[58] Kuncoro, M., Strategi bagaimana meraih keunggulan kompetitif (Erlangga, Jakarta 2005)

[59] Lennon, A., and Wollin, A., Learning organisations: Empirical investigating metaphors, Journal of Intellectual Capital, 2(4), 2005, 410-22

[60] O'Regan, N., and Ghobadian, A., The importance of capabilities for strategic direction and performance, Management Decition, 42(2), 2004, 292-312

[61] Hsu, Y., and Fang, W., Intellectual capital and new product development performance: The mediating role of organizational learning capability, Technological Forecasting \& Social Change, 76, 2009, 664-677

[62] Kaplan, S.P., and Norton. D.P., Linking the balance scorecard to strategy, California Management Review, 39(1), 1996, 53-79

[63] Auh, S., and Menguc, B., Diversity at the executive suite: A resource-based approach to the customer orientation-organizational performance relationship, Journal of Business Research, 59, 2006, 564-572

[64] Kim. E., and Lee., B., An economic analysis of customer selection and leveraging strategies in a market where network externalities exist, Decision Support Systems, 2007, 124-134

[65] Yang, C., Fang, S., and Linc, J.L., Organisational knowledge creation strategies: A conceptual framework, International Journal of Information Management, 30, 2010, 231-238

[66] Welbourne, T.M., and Pardo-del-Val, M. Relational capital: Strategic advantage for Small and Medium-size Enterprises (SMEs) through negotiation and collaboration, Group Decis Negot,18, 2009, 483-497

[67] Tseng, S., A study on customer, supplier, and competitor knowledge using the knowledge chain model. International Journal of Information Management, 29, 2009, 488-496

[68] Muchtolifah, Pengaruh sumber daya manusia, orientasi pasar, orientasi kewirausahaan terhadap strategi bersaing dan kinerja rumah sakit. Malang: Disertasi Program Doktor Fakultas Ekonomi, Universitas Brawijaya, Unpubliced, 2008

[69] Finney, R.Z., Cambell, N.D., and Powell, C.M., Strategies and resources: Pathways to success, Journal of Business Research, 58, 2005, 1721-1729

[70] Amoako-Gyampah, K., and Acquaah, M.. Manufacturing strategy, competitive strategy and firm performance: An empirical study in a developing economy enviroment, International Journal of Production Economics, 111, 2008, 575-592

[71] Kong, E., and Thomson .S.B., An intellectual capital perspective of human resource strategies and practices, Knowledge Management Research \& Practice, 7, 2009, 356-364

[72] Edelman, L.F., The mediating role of strategy on small firm performance, Journal of Business Venturing, April 2002

[73] Mathias, P. F., and Capon, N., Managing strategic customer relationships as assets: developing customer relationship capital (Working Paper, Columbia Business School, New York 2003

[74] Fang, E., Palmier, R.W., and Grewal R., Effects of customer and innovation asset configuration strategies on firm performance. Journal of Marketing Research, XLVIII, 2011, 578-602

[75] Musyarofah, S., Pengaruh penggunaan anggaran dan gaya management pengaruh penggunaan anggaran dan gaya management terhadap hubungan antara perubahan strategik dan kinerja organisasi, JAAI, 8(1), 2004

[76] Santos-Vijande, M.L., López-Sánchez, J.A., and Trespalacios, J.A., How organizational learning affects a firm's flexibility, competitive strategy, and performance, Journal of Business Research, 2011. 